\title{
Employability Study of the Business Administration Graduates of Catholic Educational Institution
}

\author{
Karen Joy A. Catacutan ${ }^{1, *}$, Fe Rose-Anne Maramag ${ }^{2}$, Mary Ann Bartolome², Rose Marie Hiquiana ${ }^{2}$, \\ Marie Jean Mendezabal ${ }^{3}$
}

\begin{abstract}
${ }^{1}$ Center for Business Research and Development, University of Saint Louis, Philippines
${ }^{2}$ School of Accountancy, Business and Hospitality, University of Saint Louis, Philippines

${ }^{3}$ University Research and Development Center, University of Saint Louis, Philippines
\end{abstract}

Received October 30, 2019; Revised November 25, 2019; Accepted December 4, 2019

Copyright $\subseteq 2020$ by authors, all rights reserved. Authors agree that this article remains permanently open access under the terms of the Creative Commons Attribution License 4.0 International License

\begin{abstract}
The employability of university graduates is a concern in higher education as labor markets change more and more rapidly. This study assessed the employment status of Business Administration (BA) graduates for the past five years and the skills and competencies acquired in the University from what competencies desired in the industry. The study used descriptive research design and there were 875 BA graduates-respondents. Results of the survey showed that majority of the graduates are employed on a permanent status and were able to get employed for an average of four months after graduation. It also showed that majority works in an industry that is directly aligned to their course or expertise and the learned skills/competencies are valuable and suitable in their jobs. Furthermore, it revealed that communication skills, human skills and decision making skills are the soft skills/competencies that they learned in the University and are useful in their present jobs. Meanwhile, among the Marketing graduates, advertising skills, marketing plan preparation and service/product presentation skills are the top three learned hard skills in the University while among the Finance and Financial Management graduates, their top three are financial report preparation, cash management and technical analysis.
\end{abstract}

Keywords Employability, Business Administration Graduates, Skills and Competencies, Catholic Educational Institution

\section{Introduction}

Graduates are faced with the challenge of acquiring employment right after graduation. It is paramount that they should have gained the best knowledge and skills in their field of specialization before plunging into any workplace of their choice. A school plays a very important role in providing higher education courses to students who will eventually become graduates with full competence in their fields of study (Ballon, 2007). To keep pace with global competition, fresh graduates need to adapt to the new business environment and workplace demands. The key element to enable graduates to keep up with those demands seems to be the employability skills and traits that are imparted during tertiary education. It has also become a common belief in industry that higher education institutions should equip graduates with the proper skills necessary to achieve success in the workplace (Robinson \& Garton, 2007).

A school should offer higher education courses that will provide students with the necessary tools which will enable them to develop their employability skills heighten their awareness of these skills and improve their ability to articulate them. These acquired skills must be honed throughout one's working life. Put into practice not only in job search and interviews but also in personal development planning and in making the most of work experience opportunities (Debono, Debono \& Caruana, 2005). Moreover, career and employability skills should be taught in schools, since many students leave education without the requisite skills to succeed in the adult work world (Zinser 2003). Furthermore, it should be emphasized that graduates should leave higher education better in many ways than when they enter it (Washer, 2007). This improvement should be attributable to the undergraduate curriculum which is important to equip them with skills they can use to 'sell themselves' to employers (Latisha \& Surina, 2010). Providing students with the opportunities to gain the necessary skills, knowledge, understanding and attributes is obviously important, but so too is providing opportunities for reflection on and evaluation of the 
learning experiences that have already taken place. Without these opportunities, a student is unlikely to give full consideration to how far they have come in developing their employability and what they may need to do in order to develop it further (Pool \& Sewell, 2007).

The Commission for Higher Education (CHED) survey indicates that Business Administration course is an oversubscribed course as there are 724,215 enrollees of the course in 2009-2010 from a total of 2,770,965 enrollees in all disciplines. According to CMO No.39 s2006, graduates of a BSBA program should be able to: convey ideas clearly both oral and written in English, prepare, analyze, and evaluate reports, proposals and concept papers, demonstrate the values of fairness, transparency, accountability, hard work, honesty, patience, diligence, innovativeness and risk taking, apply the principles of the different forms of communication, develop the ability to access, retrieve and disseminate information using it, perform quality work, understand the concepts and principles of good interpersonal relations, develop a wholesome personality, participate actively in business associations and comply with their policies and obligations, demonstrate leadership qualities, civic-mindedness and responsible citizenship, conduct environmental scanning, conduct feasibility study and other business research/plan, explain the concepts, approaches, and techniques of environmental conservation, and know and understand the country's national development thrusts, concerns and socio-economic indicators.

Many jobs require some sort of skills and experience. These skills may not be very advanced or can be acquired for a long period of time, but these normally are required by employers or are necessary on a type of work. Lack of recent work experience, out-of-date skills, growing lack of confidence, personal or behavioral problems may be reasons for not being employed. Other organizations find it safer to employ those who had previous employment or have been out of work for a short period of time. Shafie \& Nayan (2010) mentioned that employers today are concerned about finding good workers who not only have basic academic skills like reading, writing, science, mathematics, oral communication and listening, but also higher order thinking skills like learning, reasoning, thinking creatively, decision making and problem solving. Besides, they are also looking for employees that have personal qualities that among all include responsibility, self-confidence, self-control, social skill, honest, have integrity, adaptable and flexible, team spirit, punctual and efficient, self-directed, good work attitude, well-groomed, cooperative, self-motivated and self-management. However, most of our graduates are not aware of this current phenomenon whereby they sometimes don't see the connection on what they do in class with the real job world that they will venture into later.
It is in this light that this study is undertaken to determine the status of employability of Business Administration graduates of the University of Saint Louis (USL), one of the Congregatio Immaculati Cordis Mariae (CICM) Catholic Educational Institutions and Higher Educational Institutions (HEIs) in the Philippines. This study attempts to add knowledge about the need to use tracer study for the enhancement of quality course programs offered in HEIs to be able to respond to the needs of globalization. Findings of the study will assist policy planners, educators and decision makers of the School of Business Administration and Accountancy and the University of Saint Louis in the enrichment of curriculum and improvement of the university in general. Furthermore, it provides knowledge to students on what specific skills and competencies to develop and enhance for greater chance of employability.

Specifically, it addresses the following objectives:

1. To determine the employment status of Business Administration graduates

2. To identify the soft and hard skills useful in their present employment

3. To assess the Business Administration program of USL in relation to the hard and soft skills acquired in the University with the competencies needed by the industry

4. To identify the areas for further improvement of the program and the University

\section{Materials and Methods}

The study used the descriptive survey method of research. The respondents were the graduates of Business Administration program from SY 2011-2012 to SY 2015-2016. A total of $873(72.69 \%)$ graduates within the five-year period were traced using the Tracer Survey questionnaire sent to graduates through e-mail, social network and through the students of the university who are friends and relatives of the graduates. Table 1 presents the distribution of Business Administration graduates traced in the study. The survey questionnaire was also uploaded in the school's website and social network for the graduates to conveniently answer specially those working outside Tuguegarao and abroad. The questionnaire includes the employment status of graduates and the skills and competencies acquired in school in terms of soft and hard skills. It also includes recommendations and suggestions to further improve the Business Administration program of the university. The questionnaire was validated by the Institutional Research and Publication Office (IRPO) before it was distributed to the graduates. Descriptive statistics such as frequency, percentage and ranks were used to analyze data. 
Table 1. Distribution of Business Administration Graduates Traced

\begin{tabular}{|c|c|c|c|}
\hline Year & $\begin{array}{c}\text { No. of } \\
\text { Graduates }\end{array}$ & $\begin{array}{c}\text { No. of Traced } \\
\text { Graduates }\end{array}$ & $\begin{array}{c}\text { Percentage of Traced } \\
\text { Graduates }\end{array}$ \\
\hline 2012 & 201 & 148 & 73.63 \\
\hline 2013 & 281 & 148 & 52.67 \\
\hline 2014 & 264 & 210 & 79.55 \\
\hline 2015 & 213 & 175 & 82.16 \\
\hline 2016 & 242 & 192 & 79.34 \\
\hline Total & 1,201 & 873 & 72.69 \\
\hline
\end{tabular}

\section{Results and Discussion}

Table 2 reveals that majority $(85.58 \%)$ of the graduates traced are employed, with regular or permanent status and are working locally. About $2.5 \%$ of the graduates are self-employed who managing their own business or family business. It further shows that there are about $9 \%$ who are not employed because they are pursuing post-graduate studies and law school while some did not really look for a job due to family concern and other reasons.

Table 2. Status of Employment of Graduates in terms of Present Occupation

\begin{tabular}{|c|c|c|c|}
\hline \multicolumn{2}{|c|}{ Employment Status } & Frequency & Percentage \\
\hline \multirow{2}{*}{ Employed } & Managerial & 22 & 2.52 \\
\hline & Non-Managerial & 747 & 85.56 \\
\hline \multicolumn{2}{|c|}{ Self-Employed } & 22 & 2.52 \\
\hline \multicolumn{2}{|c|}{ Not Employed } & 55 & 6.30 \\
\hline \multicolumn{2}{|c|}{ Never Employed } & 27 & 3.09 \\
\hline \multirow{3}{*}{$\begin{array}{c}\text { Present } \\
\text { Employment } \\
\text { Status }\end{array}$} & $\begin{array}{l}\text { Regular or } \\
\text { Permanent }\end{array}$ & 554 & 71.22 \\
\hline & $\begin{array}{l}\text { Temporary/ } \\
\text { Probationary }\end{array}$ & 48 & 6.43 \\
\hline & $\begin{array}{c}\text { Casual/ } \\
\text { Contractual }\end{array}$ & 167 & 22.36 \\
\hline \multirow{2}{*}{ Place of Work } & Local & 727 & 94.54 \\
\hline & Abroad & 42 & 5.46 \\
\hline
\end{tabular}

As gleaned in table 3, about $64 \%$ of the graduates traced were able to get a job within 1-3 months after graduation while there are very few who got employed for more than 9 months waiting time. On the average, it took 4 months waiting time before the graduates were employed. This implies that BA graduates can easily land in a job despite having few/limited course-related employment opportunities. This is consonance to the findings that graduates waiting time ranged from less than a month to 1-6 months (Rocaberte, 2016; Ballon, 2007).

Table 3. Waiting Time of Graduates to Get Employed

\begin{tabular}{|c|c|c|}
\hline Length of time to get employed & Frequency & Percentage \\
\hline $1-3$ months & 491 & 63.85 \\
\hline $3-6$ months & 159 & 20.68 \\
\hline $7-9$ months & 60 & 7.80 \\
\hline More than 9 months & 59 & 7.67 \\
\hline Average waiting time & 4 months & \\
\hline
\end{tabular}

Meanwhile, table 4 shows the nature of job of the graduates. It shows that less than half $(43 \%)$ of the graduates are working as accounting staff (e.g. cashiers, bookkeeper, accounting clerk, accounts payable analysts, etc.) and administrative aide/assistant. About $5 \%$ of the graduates are teachers, police officers, fire officers and OFW. Most of the graduates are currently under private companies to which their expertise are directly aligned (e.g. accounting staff, finance staff, auditing staff, sales and marketing staff, etc.) while almost $7 \%$ of the graduates works in the government under casual status or job order status. Prevalent reasons for graduates' unemployment was "no job opportunity" \& "lack of knowledge" (Rocaberte, 2016).

Table 4. Nature of Job

\begin{tabular}{|c|c|c|}
\hline Nature of Job & Frequency & Percentage \\
\hline Accounting & 197 & 25.62 \\
\hline Administrative/Aide/Assistant & 137 & 17.82 \\
\hline Finance & 86 & 11.18 \\
\hline Marketing & 70 & 9.10 \\
\hline Sales & 56 & 7.28 \\
\hline Banking & 54 & 7.02 \\
\hline Government Employee & 51 & 6.63 \\
\hline Auditing & 26 & 3.3 \\
\hline Analysts & 19 & 2.47 \\
\hline Teaching & 19 & 2.47 \\
\hline Police Officer & 17 & 2.21 \\
\hline Manufacturing/Production & 9 & 1.17 \\
\hline Information Technology & 9 & 1.17 \\
\hline Consultant & 8 & 1.04 \\
\hline Human Resource & 5 & 0.65 \\
\hline Overseas Filipino Worker & 3 & 0.39 \\
\hline Fire Officer & 3 & 0.39 \\
\hline
\end{tabular}

Table 5 discloses that almost half of the respondents are new to their job as they have been in the position for less than a year. About $50 \%$ of the traced graduates have stayed in their jobs for 1-4 years and very few are in their jobs for more than 4 years. This is so because this tracer study was conducted among the graduates of the university from SY 2011-2012 to SY 2015-2016 which is just 5 years ago and some of the traced graduates switch one job from the other.

Table 5. Number of Years in the Present job

\begin{tabular}{|c|c|c|}
\hline Number of Years in the Present Job & Frequency & Percentage \\
\hline Less than 1 year & 374 & 48.63 \\
\hline 1-2 years & 247 & 32.12 \\
\hline 3-4 years & 135 & 17.56 \\
\hline More than 4 years & 13 & 1.69 \\
\hline
\end{tabular}

In table 6 , it reflects the soft skills learned in the University and are useful in the present job of graduates. It shows that the top 3 soft skills learned in the University are communication skills, human relation skills and decision 
making skills. The same skills are found to be useful in the present job of the graduates. This implies that BA graduates are honed both in oral and written communication skills Moreover, the students abide with Christian values that affected their human relations. Meanwhile, the decision making skills of the graduates was developed through the activities given to them and the assessment tools used in their major subjects like case analysis, case presentation, argumentations, debate session and others.

Table 6. Soft Skills/ Competencies Learned in the University and Useful in Present Job

\begin{tabular}{|c|c|c|c|c|}
\hline \multirow{2}{*}{$\begin{array}{c}\text { Soft } \\
\text { Skills/Competencies }\end{array}$} & \multicolumn{2}{|c|}{$\begin{array}{c}\text { Learned in the } \\
\text { University }\end{array}$} & \multicolumn{2}{c|}{$\begin{array}{c}\text { Useful in Present } \\
\text { Job }\end{array}$} \\
\cline { 2 - 5 } & Freq. & Rank & Freq. & Rank \\
\hline Communication Skills & 618 & $1^{\text {st }}$ & 575 & $1^{\text {st }}$ \\
\hline Analytical Skills & 346 & $10^{\text {th }}$ & 314 & $9^{\text {th }}$ \\
\hline Human Relation Skills & 555 & $2^{\text {nd }}$ & 512 & $2^{\text {nd }}$ \\
\hline Commitment to Work & 332 & $11^{\text {th }}$ & 305 & $10^{\text {th }}$ \\
\hline Problem-Solving Skills & 519 & $4^{\text {th }}$ & 433 & $5^{\text {th }}$ \\
\hline Decision Making Skills & 535 & $3^{\text {rd }}$ & 467 & $3^{\text {rd }}$ \\
\hline Critical thinking skills & 452 & $7^{\text {th }}$ & 416 & $6^{\text {th }}$ \\
\hline Creative thinking skills & 469 & $6^{\text {th }}$ & 391 & $8^{\text {th }}$ \\
\hline Supervisory skills & 267 & $15^{\text {th }}$ & 241 & $15^{\text {th }}$ \\
\hline Self-directed learning & 289 & $13^{\text {th }}$ & 253 & $14^{\text {th }}$ \\
\hline Teamwork & 421 & $8^{\text {th }}$ & 408 & $7^{\text {th }}$ \\
\hline Work Ethics & 354 & $9^{\text {th }}$ & 297 & $11^{\text {th }}$ \\
\hline Flexibility & 287 & $14^{\text {th }}$ & 282 & $12^{\text {th }}$ \\
\hline $\begin{array}{c}\text { Resource Management } \\
\text { Skills }\end{array}$ & 299 & $12^{\text {th }}$ & 257 & $13^{\text {th }}$ \\
\hline Computer skills & 501 & $5^{\text {th }}$ & 450 & $4^{\text {th }}$ \\
\hline
\end{tabular}

The skills or competencies learned are already manifested among the students as they play their respective functions or tasks in their workplace which is likely the same skills required in their jobs. This confirms the results of the study of Singh (2008) that the competencies learned in the University that are found very useful were communications skills, human relations skills, computer skills, critical thinking skills and problem solving skills. Graduates' employability is influenced by such skills/ competencies. Problem solving, functioning well in stressful situations, ability to work independently and maintaining a positive attitude were the highly rated skills according to importance. In relation, the most important generic competency required by the graduates was the acquisition of high levels of written communication skills. Whilst the majority of the graduates felt their education had equipped them with transferable written skills, this was not the case when discussing oral presentation skills. Although many of the graduates felt that their education had not provided them with the necessary level of oral communication skills required in the work environment, many felt that their university experiences of group-work had provided them with vital team-working skills (Andrews, 2008). While, communication skills, human relations, and information technology skills were found to be the top three competencies found to be the most useful to graduates in order to land on their first job (Ballon, 2007).

While in Table 7, it shows that the top three hard skills learned in school by Marketing graduates are advertising skills, marketing plan preparation and service/ product presentation skills whereas the top three hard skills found to be useful to the present job of graduates are advertising skills, sales report preparation and product proposal presentation. This shows that the University prepares its Marketing graduates to be well prepared and ever ready to work in the industry. That through the curriculum and assessment tools in their major subjects, their skills in making advertisements like TV ads, print ads, radio ads, their skills in presenting product proposals that are creative/innovative and their skills on preparing both marketing plan and sales report are properly ensured by their subject teachers with the proper support of the department and the University as a whole.

Table 7. Skills/ Competencies in Marketing that are Useful in Present Job

\begin{tabular}{|c|c|c|c|c|}
\hline \multirow{2}{*}{ Hard Skills } & \multicolumn{2}{|c|}{$\begin{array}{c}\text { Learned in the } \\
\text { University }\end{array}$} & \multicolumn{2}{c|}{ Useful in Job } \\
\cline { 2 - 5 } & Freq. & Rank & Freq. & Rank \\
\hline $\begin{array}{c}\text { Product proposal } \\
\text { presentation }\end{array}$ & 37 & $8^{\text {th }}$ & 33 & $3^{\text {rd }}$ \\
\hline $\begin{array}{c}\text { Service/ product } \\
\text { presentation skills }\end{array}$ & 42 & $3^{\text {rd }}$ & 31 & $5^{\text {th }}$ \\
\hline Product innovation & 33 & $10^{\text {th }}$ & 23 & $9^{\text {th }}$ \\
\hline SWOT analysis & 38 & $6^{\text {th }}$ & 32 & $4^{\text {th }}$ \\
\hline Sales report preparation & 39 & $5^{\text {th }}$ & 35 & $2^{\text {nd }}$ \\
\hline Marketing analysis & 40 & $4^{\text {th }}$ & 25 & $8^{\text {th }}$ \\
\hline $\begin{array}{c}\text { Marketing plan } \\
\text { preparation }\end{array}$ & 46 & $2^{\text {nd }}$ & 30 & $6^{\text {th }}$ \\
\hline Market segmentation & 38 & $6^{\text {th }}$ & 28 & $7^{\text {th }}$ \\
\hline Advertising skills & 49 & $1^{\text {st }}$ & 41 & $1^{\text {st }}$ \\
\hline Event management & 34 & $9^{\text {th }}$ & 20 & $10^{\text {th }}$ \\
\hline Other skills & 1 & $11^{\text {th }}$ & 2 & $11^{\text {th }}$ \\
\hline
\end{tabular}

Given the present curriculum in the University, it is a status quo that advertising skills and service/product presentation skills are well taught of. However, it is important to note that currently, there is no separate subject that is offered in the curriculum that solely focused on sales report/product proposal presentation. These particular skills are only demonstrated in some assessment tools among the existing major subjects in the curriculum.

As shown in the table 8, the top three hard skills learned in school by Finance and Financial Management graduates are financial report preparation, cash management and technical analysis while the hard skills that are useful in the present job of the graduates are financial report preparation, cash management and banking systems and processes. The 
results imply that Finance and Financial Management graduates are properly equipped with the hard skills needed in their respective jobs/industry. Given their major subjects, students are well trained of preparing financial reports and proper handling/management of cash. It is evident that in the curriculum of Financial Management course, subjects like Financial Analysis and Reporting, Financial Management and Strategic Financial Management that the skills mentioned were being emphasized.

Table 8. Skills in Finance/ Financial Management that are Useful in Present Job

\begin{tabular}{|c|c|c|c|c|}
\hline \multirow{2}{*}{ Hard Skills } & \multicolumn{2}{|c|}{$\begin{array}{c}\text { Learned in the } \\
\text { University }\end{array}$} & \multicolumn{2}{c|}{ Useful in Job } \\
\cline { 2 - 5 } & Freq. & Rank & Freq. & Rank \\
\hline $\begin{array}{c}\text { Financial report } \\
\text { preparation }\end{array}$ & 375 & $1^{\text {st }}$ & 321 & $1^{\text {st }}$ \\
\hline Financial analysis & 274 & $7^{\text {th }}$ & 200 & $6^{\text {th }}$ \\
\hline Aging of receivables & 225 & $11^{\text {th }}$ & 163 & $9^{\text {th }}$ \\
\hline SWOT analysis & 283 & $6^{\text {th }}$ & 224 & $4^{\text {th }}$ \\
\hline $\begin{array}{c}\text { Credit policies } \\
\text { formulation }\end{array}$ & 241 & $8^{\text {th }}$ & 180 & $7^{\text {th }}$ \\
\hline $\begin{array}{c}\text { Counterfeit money } \\
\text { detection }\end{array}$ & 294 & $5^{\text {th }}$ & 162 & $10^{\text {th }}$ \\
\hline Cash management & 334 & $2^{\text {nd }}$ & 261 & $2^{\text {nd }}$ \\
\hline Technical analysis & 303 & $3^{\text {rd }}$ & 217 & $5^{\text {th }}$ \\
\hline $\begin{array}{c}\text { Banking systems and } \\
\text { processes }\end{array}$ & 295 & $4^{\text {th }}$ & 234 & $3^{\text {rd }}$ \\
\hline Economic analysis & 232 & $9^{\text {th }}$ & 175 & $8^{\text {th }}$ \\
\hline Bond valuation & 202 & $12^{\text {th }}$ & 132 & $12^{\text {th }}$ \\
\hline Stock valuation & 228 & $10^{\text {th }}$ & 151 & $11^{\text {th }}$ \\
\hline $\begin{array}{c}\text { Other skills } \\
\text { Manyyy}\end{array}$ & 18 & $13^{\text {th }}$ & 9 & $13^{\text {th }}$ \\
\hline
\end{tabular}

Though comes $4^{\text {th }}$ as a skill learned in the University and $3^{\text {rd }}$ to be useful in the job, Financial Management and Finance graduates are well taught of the different banking systems and process because some graduates were exposed to the different banks during their on-the-job training and classroom simulations. Also, skill on banking systems and processes was implied to be found useful in the banking industry and this particular skill is developed among students in the University especially under their subjects on Bank Management, Bank and Non-Bank and Financial Management. However, in the 2004/2007/2014 curriculum, there is now an only one subject where this skill is taught and that is Bank and Nonbank Management. Lastly, table 9 reveals that the top three areas recommended for further improvement in the University are its curriculum, instruction and school services. For its curriculum, the graduates recommend that there should be an inclusion of Systems Applications and Products, provision of more seminars for the students to be exposed to different workshops that will enhance their skills and the inclusion of first year to fourth year students to the seminars that are to be held outside the school. Also, there should be a separate semester for OJT programs in order for the students to be well prepared and trained in the work environment and if possible, OJT should be conducted outside Tuguegarao for BA students for better exposure. For the instruction, it is recommended that the faculty should improve their discipline in communicating, faculty should enhance the skills of the students in their respective fields in a manner that the teacher should not focus on the theoretical aspects and they should be trained more for enhanced computer skills especially in MS office. It is also recommended that for school services, the university should provide internet connection or additional computer laboratory for students to work, that the enrolment system should be fast and the enrolment procedures should be easy to follow or understand, there should be no noon-break policy during the payment periods during exams, and also, there should be a wider library because the space is not enough especially during exam for the students to review and the library should have more books if possible.

Table 9. Recommendations for University Improvement

\begin{tabular}{|c|c|c|}
\hline Recommendations & Frequency & Rank \\
\hline Curriculum & 76 & 1st \\
\hline Instruction & 49 & 2nd \\
\hline Physical Plant Facilities & 25 & 4 th \\
\hline School Services & 32 & 3rd \\
\hline Faculty & 14 & 5 th \\
\hline Affiliation/ Linkages & 5 & 7th \\
\hline Administration & 12 & 6th \\
\hline
\end{tabular}

On the other areas, for physical plant, it is recommended that the school should have a more developed and improved school facilities (e.g., projectors, computer sets, fans, chairs, etc.) and the classrooms should be airconditioned. For the faculty, the university should always hire the best educators/faculties, should empower and encourage continuous professional development of the faculty and that the faculty should deliver lectures using new techniques. The school should also invite professionals/experts to deliver lectures. For affiliation/linkages, the university should build stronger reputation, should collaborate with other institutions and should develop student ties/affiliates outside the school. And lastly, for the administration, it is recommended that administrators should be student-friendly, open to suggestions and ideas for improvement.

\section{Conclusions}

The study concludes that majority of the BA graduates from SY 2011-2012 to SY 2015-2016 are employed and are highly employable since they got employed for less than a year. Most of them are now permanent or regular in their respective jobs. Both Marketing and Financial Management/Finance graduates were able to learn and develop the hard skills and soft skills/competencies 
needed or required by the industry.

It can be further concluded that through the years, USL were able to produce BA graduates that are highly competent and professionally ready to work in their respective industries because they were holistically developed while they are in the University. Moreover, the BA graduates were able to acquire the highly necessary skills and competencies which made them hired or employed on a regular/permanent basis.

\section{Recommendations}

Employability of graduates is highly dependent on qualifications sought by the labor market. Graduates should possess communication skills, human relation skills, computer skills and ability to work under pressure to have greater chance of being employed. Academic institutions therefore should develop these skills to their students to increase likelihood of desired employability.

With all the findings of the study, it is recommended that University should review the recommendations shared by the BA graduates. Among these recommendations that needs to be considered are: the need to review the curriculum particularly on offering major subjects that shall focus on the enhancement of both hard and soft skills/competencies that are expected among the graduates, the possibility of returning the Bank Management subject under the Business Administration major in Financial Management, the exposure of the BA students to a more realistic on-the-job training within and outside the province, the necessity to improve facilities of the university, the hiring of well-experienced and trained professors to develop more the skills and knowledge of the students to match the needs of the industry, the conduct/provision of seminars/trainings to complement the students' theoretical knowledge learned in the classroom in a more realistic setting/environment.

Furthermore, this study can be replicated by other institutions in the city and in the region to trace their own graduates and to investigate their employability status. Such results of the study can be used to improve their own current educational system.

\section{REFERENCES}

[1] Ballon, A. E. (2007). Predictors of Employability of the Graduates of Technological Institute of the Philippines Quezon City. TIP Research Journal Quezon City, 4(1), 1-1.

[2] Debono, M., Debono, A., \& Caruana, N. (2005). Career outcomes of graduates 2004: A career guidance tool.

[3] Dacre Pool, L., \& Sewell, P. (2007). The key to employability: developing a practical model of graduate employability. Education+ Training, 49(4), 277-289.
[4] Robinson, J. S., \& Garton, B. L. (2008). An Assessment of the Employability Skills Needed by Graduates in the College of Agriculture, Food and Natural Resources at the University of Missouri. Journal of agricultural education, 49(4), 96-105.

[5] Rocaberte, TG (2016). The University of Pangasinan graduate tracer study.

[6] Shafie, L. A., \& Nayan, S. (2010). Employability awareness among Malaysian undergraduates. International Journal of Business and Management, 5(8), 119.

[7] Singh, G. K. G., \& Singh, S. K. G. (2008). Malaysian graduates' employability skills. UNITAR e-Journal, 4(1), $15-45$.

[8] Washer, P. (2007). Revisiting key skills: A practical framework for higher education. Quality in Higher Education, 13(1), 57-67.

[9] Zinser, R. (2003). Developing career and employability skills: A US case study. Education+ Training, 45(7), 402-410. 